\title{
College Physical Education Curriculum Reform and the Cultivation of College Students' General Ability
}

\author{
Li Wenfang \\ Xi'an Eurasia University, Xian, 710065, China
}

Keywords: college physical education curriculum reform; college students; general ability training

\begin{abstract}
The physical education curriculum is an important part of college curriculum. Through the development of the physical education curriculum, students can get better physical exercise, and then cultivate physical quality, which is of great significance to the development of students' physical healthy, psychology and character. But at present, there are still many problems in the teaching of physical education courses in our country. Therefore, the study on the reform of college physical education curriculum and the cultivation of contemporary college students' general ability have become the subject of the physical education teachers in colleges and universities. This paper aims to study the reform of physical education curriculum and the general ability of college students.
\end{abstract}

\section{The Concept of Physical Education Curriculum in Colleges and Universities}

The so-called college physical education curriculum concept, in essence, is the general concept of people in the function of college physical education curriculum, and the general concept formed. However, as far as the present social situation is concerned, the meaning of health is not only physical health, people's mental health is gradually being paid attention to by science. Therefore, the concept of College Physical Education Curriculum in the new era should be to let the students improve their physical and mental adaptability through the study of physical education, and stimulate the enthusiasm of the students in physical exercise, and let the students have a better personal development. Based on this, the physical education curriculum in Colleges and universities must be reformed and the thought is always carried out. Conclusion and theoretical innovation, and then better find the problems in the teaching of physical education in Colleges and universities, to solve the problems in the teaching of physical education in Colleges and universities, and to cultivate the general knowledge of contemporary college students so that the development of physical education in Colleges and universities will be further developed and usher in the spring of development [1].

\section{The Problems of Physical Education in Colleges and Universities}

For the time being, the problems in physical education curriculum in universities lie in the structural imbalance of physical education curriculum. The course of physical education in Colleges and universities should be the course of the practice of superfluous theory. In our impression, the college physical education curriculum should pay attention to the development of sports activities and neglect the study of sports theory knowledge. But in the actual teaching, it is not like this. At the present stage, the physical education course in Colleges and universities is teaching in the actual classroom teaching. Far more than extracurricular sports activities, this kind of curriculum imbalance teaching mode is contrary to the concept of physical education in Colleges and universities. In addition, many colleges and universities in China lack clear guidance in the process of the deployment of physical education, which directly causes the lack of clear division of physical education and the lack of effective development of the students' extracurricular sports activities. It seriously endangers the development of physical education curriculum in Colleges and universities [2].

At present, the problems existing in college physical education curriculum are reflected in the 
lack of timeliness of physical education curriculum in Colleges and universities. The development of physical education curriculum in Colleges and universities needs timeliness, which is because only the physical education curriculum has good timeliness, students can better improve the interest in participating in physical exercise, and then enrich the sports curriculum theory and promote the healthy development of the students. At present, although the sports education in our university has added a lot of new sports items to the project, and the teaching material is constantly enriching, but this kind of physical education is still lack of timeliness, and many new sports are not included in the college sports teaching materials, such as street dance. Yoga, roller skating, and so on. To sum up the reasons for this problem, the author believes that there is a great relationship between this and the importance of college leaders to the importance of sports curriculum. In addition, many college teachers have not the ability to compile the curriculum. Furthermore, there are problems in the teaching model in the course of physical education in colleges and universities. The reason directly led to the lack of timeliness in physical education teaching in Colleges and universities, which is very unfavorable for the development of College Students' physical training.

At present, the problems existing in the physical education curriculum in Colleges and universities are also reflected in the backward teaching methods of physical education. According to the author's incomplete investigation, there are no definite changes in the Chinese sports education system in the primary school and the University. In the course of physical education, we often see that teachers use traditional teaching methods to carry out physical education, and the teaching method is basically the important teaching method. Means, the teaching mode is single, the students lack interest, only in order to cope with the final physical examination and carry out mechanical exercises, make the classroom atmosphere very dull, such a physical education course seriously affects the effectiveness of the teaching of physical education in Colleges and universities. At the same time, it also affects the students to treat physical education to a great extent. Cheng's psychology has made the physical education curriculum lose its important position [3].

\section{The Importance of Developing Students' General Knowledge in Physical Education Courses}

Cultivating students' general knowledge in PE Teaching in Colleges and universities can enhance students' comprehensive quality. To cultivate students' general ability is a teaching concept that respects the development of students' personality. Under this educational idea, students can better carry out the elective course of physical education, fully respect the personality characteristics of the students, abandon the compulsory teaching of the traditional college physical education curriculum, through such ability training, students can To develop better personality, enhance creativity and confidence in learning, so as to better stimulate students' enthusiasm for learning, to enable students to develop in an all-round way, and to improve their comprehensive quality while completing interest and learning.

Cultivating students' general knowledge in PE Teaching in Colleges and universities can enhance students' humanistic spirit. Physical education can really strengthen our physique in a real sense, but strong physique is just a simple level of physical exercise spirit. In physical education, its core idea is not only to use physical exercise to strengthen physical fitness, but also to use physical exercise to promote the overall development of human beings and promote people. It believes that spirit can further promote social harmony and speed up social civilization construction. Therefore, in the college physical education curriculum training students' understanding ability, can be good to excavate the humanistic thought in the teaching of physical education, and let the students understand the social and humanistic ideas of competition, democracy and cooperation in the study of physical education curriculum, and then promote the humanistic spirit of the Contemporary College Students in a all-round way [4].

Cultivating students' general knowledge in PE Teaching in Colleges and universities can enhance students' adaptability. In college physical education curriculum, situational teaching and effective interaction between teachers and students are important teaching forms that other disciplines do not possess. Through specific communication, teachers and students or students are more likely to form 
a good learning atmosphere. This is for the students' future in the community and ability literacy in the future. It is a specific promotion. In addition, I mentioned in the previous article that the physical education curriculum emphasizes the development of the students' personality and the degree of participation in the course. Therefore, in the study of physical education, the students can better improve their adaptability, and gradually realize their self character adjustment and self reflection, in a word, cultivating students' general knowledge in college physical education teaching is of great help to improving students' social adaptability.

Cultivating students' general knowledge in college physical education can help students develop the habit of physical exercise. In the teaching of general education of physical education in Colleges and universities, the concept of education always adheres to the habit of cultivating students to adhere to lifelong physical exercise, and it is also an important teaching goal for us to carry out the general curriculum of physical education in Colleges and universities. In addition, the physical education curriculum is starting with the students' interest in sports, fully respecting the students' personality development. In this way, the students' enthusiasm for learning will be stimulated and become very high, which is more conducive to the cultivation of students' lifelong exercise habits. Here, what we should pay attention to is how should we cultivate students' habit of lifelong exercise in general physical education courses in Colleges and universities? In general, this requires our schools and teachers to choose the appropriate and scientific teaching mode and teaching methods in the actual process of teaching, fully respect the students' personality development, impart the skills, improve the self-confidence of the students to participate in physical exercise, and let the students join in the physical exercise consciously. And help students develop good habits of lifelong exercise to promote the healthy development of students [5].

Cultivating students' general knowledge in Physical Education in Colleges and universities can effectively enhance students' physique. Through the training of general physical education in Colleges and universities, the physical quality of the students will be improved, the shape of the body building, the formation of good appearance and posture, the improvement of students' ability to resist disease, and the students' knowledge of sports, and the promotion of the students' will quality, and the students' ability to benefit. With their strong physique to carry out social production activities, and comprehensively enhance the employment rate of students, so that students in the future development can take the lead in the first step.

\section{College Physical Education Curriculum Reform and General Ability Training Strategy}

In the reform of physical education in Colleges and universities, teachers should first change the concept of physical education. Changing the concept of teaching is the purpose of the reform of education. In the program of education development in China, it is clearly defined that teachers must change the educational concept in the actual process of teaching. In addition, changing the educational concept will inevitably lead to the innovation of the educational mode and the educational method. In this way, we will be able to do more. To cultivate the students' sports spirit well, set up the correct sports values for the students, let the students develop the good habit of life-long exercise, and promote the development of the reform of the physical education curriculum in Colleges and universities [6].

Secondly, we should optimize the physical education curriculum structure and enrich the content of the course. In the previous article, I have mentioned that the structure of physical education curriculum and the contents of modern colleges and universities have problems of irrational configuration and lack of timeliness. Therefore, in the reform of physical education courses in Colleges and universities, we should configure a more reasonable structure of physical education curriculum, and enrich the curriculum resources, and then satisfy the study. The desire to learn is better for the reform of physical education curriculum in Colleges and universities. In the specific reform work, we can adjust the schedule of physical education courses, at the same time encourage teachers to carry out more outdoor activities, as many as possible for students to set up some good sports activities, and improve the proportion of physical education curriculum. In addition, we should absorb more timeliness of curriculum resources, such as yoga, Pilates, taekwondo, etc., such 
as yoga, Pilates, taekwondo, etc., to enrich our physical education curriculum so that students can gain more knowledge in the study of physical education, from the real significance. We should do a good job in the reform of physical education courses in Colleges and universities.

The modern society needs compound talents, so in the reform of college physical education curriculum, we must construct the general education system, and then train the students' general ability in order to make the students better adapt to the society and occupy a place in the future social competition. At the same time, we should make full use of the physical resources in the campus during the course of the reform of college physical education, increase the input on the sports facilities, and then better meet the needs of the contemporary college students, such as the construction of the Yoga field, the roller skating field, and the full cultivation of the students' humanistic quality, and then the full training of the students' humanistic quality. The training of students' general knowledge and the reform of physical education curriculum in Colleges and universities.

In the reform of physical education in higher education, we should also build a scientific evaluation system. In the educational field, only in the teaching of one subject is the successful construction of a scientific and reasonable educational evaluation system, so that we can better test the results of the students' study, and then promote the reform of education and the healthy development. Sports education, as a special subject, has great uncertainty, such as psychological factors, learning attitude and so on. So it is difficult to find a scientific evaluation standard. If we only consider the students' mastery of sports skills in the process of evaluation. The level of students' sports will be unscientific, and it is bound to dispel the enthusiasm of students for physical exercise. Therefore, in the process of sports curriculum reform, we should better build a scientific evaluation system, fully respect the physical quality of students, and study attitude, and then allow students to participate more actively in physical exercise to realize the reform of the teaching of physical education in Colleges and universities.

In the reform of physical education curriculum in higher education, we should also pay attention to the construction of teachers' team. Teachers are the direct participants of teaching. The quality of teachers directly determines the achievements of the reform of physical education curriculum in Colleges and universities. Therefore, it is imperative to improve the quality of teachers and strengthen the construction of the teachers' team. In the course of teaching reform, our college physical education teachers must have comprehensive teaching ability and activity organization ability, and can promote students' interest in learning in the actual process of teaching, and pay more attention to the cultivation of students' ability. Here, the author suggests that we can take the form of open recruitment to enrich our teachers, so as to better build a team of teachers. Schools should also have great funds for the construction of teachers' team, and then provide better salary treatment for teachers and attract excellent educational talents to join our teaching team.

\section{Conclusion}

To sum up, the curriculum reform in College Physical Education and the training of the general ability of college students can better improve the comprehensive quality of the students in the contemporary university, make the contemporary college students have a strong physique, and help them to form a good habit of lifelong exercise and exercise. As a teacher, in the course of curriculum reform, we must pay attention to the innovation of teaching concept, at the same time, build a good general education system for students in physical education, improve the quality of the teachers, and further contribute to the physical education curriculum reform of Contemporary Colleges and universities.

\section{References}

[1] Yao Y, University X. Analysis of the curriculum reform of English teaching method and the cultivation of students' speculative ability[J]. Journal of Jiamusi Vocational Institute, 2017. 
[2] Yao Y, Zhou X, Wang G. The Curriculum Reform of Talent Cultivation and Practice on the Pharmaceutical Service of Higher Vocational Colleges[J]. Chinese Medicine Modern Distance Education of China, 2017.

[3] Liu B W, Yang L Z, Liu B W, et al. Cultivation of College Students' Scientific Literacy in the Teaching of Curriculum[J]. 2017(mess).

[4] Yue F F. Curriculum Reform of English Majors and Cultivation of Innovative Talents--A Case Study of Jining Normal College[J]. Journal of Hubei Correspondence University, 2017.

[5] Wang Q. An Empirical Study on College English Curriculum Assessment and Cultivation of Intercultural Communication Competence[J]. 2017, 5(6):417-423.

[6] Yang S Q, Li T A. College physical education reform research on the cultivation of university students' physical education lifestyle[J]. Heilongjiang Science, 2018.

A brief introduction to the author: Li Wenfang, female, Shaanxi Pucheng, August 1976, postgraduate, associate professor, physical education teaching and management 